\title{
ANIMAL RESEARCH PAPER \\ Calcium and phosphorus utilization in growing sheep supplemented with dicalcium phosphate
}

\author{
R. S. DIAS ${ }^{1}$, S. LÓPEZ ${ }^{2}$, R. M. PATIÑO ${ }^{3}$, T. S. SILVA ${ }^{4}$, J. C. SILVA FILHO ${ }^{5}$, D. M. S. S. VITTI ${ }^{4}$, \\ M.R.S.R. PEÇANHA ${ }^{4}$, E. KEBREAB ${ }^{6}$ AND J. FRANCE ${ }^{1}$ \\ ${ }^{1}$ Centre for Nutrition Modelling, Department of Animal and Poultry Science, University of Guelph, Guelph, \\ ON, N1 G 2W1, Canada \\ ${ }^{2}$ Instituto de Ganadería de Montaña, Universidad de León-Consejo Superior de Investigaciones Científicas, \\ Departamento de Producción Animal, Universidad de León, 24071 León, Spain \\ ${ }^{3}$ Facultad de Ciencias Agropecuarias, Universidad de Sucre, Carrera 28 5-267, Sincelejo, Sucre, Colombia \\ ${ }^{4}$ Centro de Energia Nuclear na Agricultura, Universidade de São Paulo, CEP 13400-970, Piracicaba, SP, Brazil \\ ${ }^{5}$ Departamento de Zootecnia, Universidade Federal de Lavras, CEP 37200-000, Lavras, MG, Brazil \\ ${ }^{6}$ Department of Animal Science, University of California, Davis, CA 95616, USA
}

(Received 2 November 2011; revised 28 May 2012; accepted 25 June 2012; first published online 21 August 2012)

\section{SUMMARY}

The objective of the current study was to evaluate the utilization of calcium (Ca) and phosphorus (P) in growing sheep consuming increasing amounts of dicalcium phosphate. Eighteen growing sheep, aged 8 months, were fed a basal diet supplemented with $0,12.5$ and $25 \mathrm{~g}$ of dicalcium phosphate/day. During the experiment, animals were injected intravenously with $7 \cdot 4 \mathrm{MBq}$ of ${ }^{45} \mathrm{Ca}$ and ${ }^{32} \mathrm{P}$ and samples of plasma, faeces and urine were subsequently taken daily for 1 week after injection. Rumen fluid was sampled on days 4-7 after injection. Specific radioactivity in plasma and in faeces were used to determine true absorption of $\mathrm{Ca}$ and $\mathrm{P}$, whereas plasmatic and ruminal specific radio-activities were used to determine endogenous $\mathrm{P}$ flow into the rumen and turnover time of rumen $\mathrm{P}$. Increasing dicalcium phosphate intake led to linear increases in faecal excretion of endogenous $\mathrm{Ca}$ and $\mathrm{P}$ $(P<0 \cdot 05)$, suggesting that surpluses of ingested $\mathrm{Ca}$ and $\mathrm{P}$ were voided through secretion to the gut. True absorption coefficients for $0,12.5$ and $25 \mathrm{~g}$ of dicalcium phosphate ingested daily were $0.54,0.41$ and 0.38 for $\mathrm{Ca}$, and 0.66 , 0.62 and 0.64 for $P$, respectively. Flows of endogenous $P$ into the rumen increased linearly and ruminal turnover time of $\mathrm{P}$ decreased linearly $(P<0 \cdot 01)$ as $\mathrm{P}$ intake was increased. Concentrations of $\mathrm{Ca}$ and $\mathrm{P}$ in bone were not affected by the increased amounts of these minerals ingested $(P<0 \cdot 05)$. In conclusion, increasing ingestion of dicalcium phosphate increases faecal excretion of $\mathrm{Ca}$ and $\mathrm{P}$, thus decreasing the efficiency of utilization of both minerals. Moreover, increasing levels of dietary $\mathrm{P}$ increased endogenous $\mathrm{P}$ excretion, contributing to the amount of $\mathrm{P}$ disposed of in the environment.

\section{INTRODUCTION}

Dicalcium phosphate is one of the most widely used sources of supplementary phosphorus (P) for all farm animal species. Although mainly used as a $\mathrm{P}$ source, the supplement also provides calcium (Ca). The availability of $\mathrm{P}$ in this supplement has been assessed by researchers in the past (Ammerman et al. 1957; Tillman \& Brethour 1958; Lofgreen 1960; O'Donovan et al. 1965). However, Ca availability from dicalcium

* To whom all correspondence should be addressed. Email: s.lopez@unileon.es phosphate has not, to the present authors' knowledge, been evaluated sufficiently despite the known interactions between the minerals.

Most of the studies carried out previously to determine $\mathrm{P}$ availability from dicalcium phosphate used methods that are not currently considered to be accurate enough (France et al. 2010). For instance, some studies assessed true $\mathrm{P}$ availability of dicalcium phosphate by considering endogenous $\mathrm{P}$ as the $\mathrm{P}$ excreted by animals fed a low-P or P-free basal diet (Ammerman et al. 1957; O'Donovan et al. 1965), which usually leads to an erroneous estimate of true 
endogenous $\mathrm{P}$ excretion. Other studies (Long et al. 1957) used the values of $P$ in plasma to compare $P$ availability from different supplements. Although plasma $\mathrm{P}$ values may provide an indication of $\mathrm{P}$ availability, its use as the only source of information to evaluate mineral availability is not recommended due to its susceptibility to metabolic changes (Vitti et al. 2010). The availability of a nutrient is more accurately established in experiments with graded intakes of the mineral source evaluated (Johnson \& McClure 1967). Studies considering only one level of intake (Tillman \& Brethour 1958; Arrington et al. 1963) of the supplement may provide incomplete information on mineral availability. Current knowledge of $\mathrm{Ca}$ and $\mathrm{P}$ availability from dicalcium phosphate remains incomplete, justifying further studies for more efficient use of this supplement given the unquestionable importance of this source of $\mathrm{P}$ for ruminant diets. The use of isotopic tracer methods in combination with mathematical modelling offers a suitable tool to investigate metabolic transactions of minerals between the body compartments (France et al. 2010). In addition, excess of $\mathrm{P}$ excreted in faeces is of major environmental concern, highlighting the importance and relevance of investigating the consequences of providing dicalcium phosphate as a dietary supplement. The objective of the current study is to investigate the effects of increasing ingestion of dicalcium phosphate by growing sheep on $\mathrm{Ca}$ and $\mathrm{P}$ absorption, excretion and utilization.

\section{MATERIALS AND METHODS}

Animal and diets

The experiment was carried out at the Animal Nutrition Laboratory, Centre for Nuclear Energy for Agriculture (CENA), University of Sao Paulo (USP), Brazil, using a protocol approved by the Commission of Ethics in Experimentation with Animals (CIEEACENA/USP) and the Commission of Environmental Ethics (CEA-CENA/USP) of CENA, USP.

Eighteen male Santa Inês sheep, initial live weight 33.7 (s.D. 1.66$) \mathrm{kg}$, aged 8 months, were randomly allocated to one of the three experimental groups (six sheep per group). The treatments consisted of a basal diet supplemented with increasing amounts of dicalcium phosphate (Serrana, Sao Paulo, Brazil). According to the supplier specifications, the commercial product (c. $0 \cdot 80 \mathrm{~g}$ dicalcium phosphate/g product) used as a supplement contained $0 \cdot 24 \mathrm{~g}$ Ca and $0 \cdot 18 \mathrm{~g}$
Table 1. Composition of experimental diets

\begin{tabular}{|c|c|c|c|}
\hline & \multicolumn{3}{|c|}{ Dicalcium phosphate (g/day) } \\
\hline & 0 & $12 \cdot 5$ & 25 \\
\hline \multicolumn{4}{|c|}{ Experimental diets (g/day) } \\
\hline Hay & 890 & 890 & 890 \\
\hline Concentrate & 249 & 249 & 249 \\
\hline Dicalcium phosphate & 0 & $12 \cdot 5$ & $25 \cdot 0$ \\
\hline \multicolumn{4}{|c|}{ Ingredient* (g/kg diet as fed) } \\
\hline Hay & 781 & 773 & 765 \\
\hline Cassava meal & 139 & 137 & 136 \\
\hline Soybean meal & 47 & 46 & 46 \\
\hline Urea & 14 & 14 & 14 \\
\hline Sugarcane molasses & 10 & 10 & 10 \\
\hline Trace mineral premix ${ }^{+}$ & 9 & 9 & 9 \\
\hline Dicalcium phosphate & - & 11 & 22 \\
\hline \multicolumn{4}{|c|}{ Analysed nutrient component (g/kg DM) } \\
\hline $\mathrm{OM}^{\prime}$ & 921 & 922 & 923 \\
\hline $\mathrm{CP}$ & 109 & 108 & 106 \\
\hline NDF & 642 & 635 & 628 \\
\hline ADF & 351 & 347 & 344 \\
\hline $\mathrm{ME}, \mathrm{MJ} / \mathrm{kg} \mathrm{DM}^{\ddagger}$ & $9 \cdot 69$ & $9 \cdot 58$ & $9 \cdot 49$ \\
\hline $\mathrm{P}$ & $1 \cdot 4$ & $3 \cdot 2$ & $4 \cdot 9$ \\
\hline $\mathrm{Ca}$ & $3 \cdot 5$ & $6 \cdot 3$ & $9 \cdot 0$ \\
\hline
\end{tabular}

$\mathrm{DM}$, dry matter; $\mathrm{OM}$, organic matter; $\mathrm{CP}$, crude protein; NDF, neutral detergent fibre; $A D F$, acid detergent fibre; $\mathrm{ME}$, metabolizable energy; $\mathrm{P}$, phosphorus; $\mathrm{Ca}$, calcium.

* Diets were supplemented with vitamin A, $1000000 \mathrm{IU} / \mathrm{kg}$; vitamin D, $250000 \mathrm{lU} / \mathrm{kg}$; vitamin E, $6250 \mathrm{lU} / \mathrm{kg}$.

+ Trace mineral premix composition per kilogram: $30 \mathrm{~g}$ magnesium, $30 \mathrm{~g}$ sulphur, $3 \mathrm{~g}$ copper, $5 \mathrm{~g}$ manganese, $12 \mathrm{~g}$ zinc, $80 \mathrm{mg}$ selenium, $180 \mathrm{mg}$ iodine.

₹ Calculated from NRC (2007).

$\mathrm{P} / \mathrm{g}$ product. The experimental basal diet was composed of roughage (chopped coast cross hay), a concentrate mixture (cassava meal, soybean meal, sugarcane molasses and urea) and a mineral mixture (Table 1). The experimental treatments comprised three diets providing $3.5,6.3$ and $9 \cdot 0 \mathrm{~g} \mathrm{Ca} / \mathrm{kg}$ dry matter (DM) and $1.4 ; 3.2$ and $4.9 \mathrm{~g} \mathrm{P} / \mathrm{kg} \mathrm{DM}$, respectively. To achieve these $\mathrm{Ca}$ and $\mathrm{P}$ concentrations, animals ingested $0,12.5$ or $25 \mathrm{~g}$ of dicalcium phosphate/day for each of the experimental diets. In all groups, sheep were fed the corresponding diet in two equal meals at 08.00 and $17.00 \mathrm{~h}$.

After a 21-day adaptation period in ground stalls, the animals were transferred to individual metabolism cages fitted with a device for separated collection of faecal and urinary outputs. The animals were maintained in the metabolism cages for 2 weeks, 6 days of adaptation and the last 8 days constituting the collection period that started when each animal received a 
single dose of $7 \cdot 4 \mathrm{MBq}$ of ${ }^{45} \mathrm{Ca}$ and ${ }^{32} \mathrm{P}$ injected into the right jugular vein. Subsequently, samples of plasma were taken by venepuncture from the left jugular vein and collected into heparin every $24 \mathrm{~h}$ up to 7 days after injection. Feed intake and the total faecal and urinary outputs were recorded daily during the collection period. Diets and feed refusals were weighed and sampled daily. All feed refusal samples from each animal were combined, so that at the conclusion of the experimental period, feed and feed refusal composites were obtained for chemical analyses. Faeces and urine were collected and weighed daily and representative aliquots (in each case 0.10 of the total amount collected) of each output were sampled and preserved in a refrigerator at $4{ }^{\circ} \mathrm{C}$. At the end of the collection period, the preserved daily samples were composited to obtain representative faeces and urine samples for each animal, which were frozen at $-20^{\circ} \mathrm{C}$ until further chemical analysis. Rumen fluid samples were taken only on days 4, 5, 6 and 7 after injection of radioactive elements to minimize stress to the animals. Rumen contents were collected using an oesophageal tube and a syringe pumping out $50 \mathrm{ml}$ of rumen sample each time of collection.

On the last day of the collection period and once all sampling was completed, the animals (which had not received feed in the last $24 \mathrm{~h}$ ) were killed by intravenous injection of $0.05 \mathrm{mg}$ of xylazine (Rompum-Bayer, Sao Paulo, Brazil)/kg of body weight (BW) followed by exsanguination. Rumen volume (I) was measured and samples of the third and fourth metatarsal bones were collected.

\section{Sample preparation}

Feed and feed refusal samples were dried at $60{ }^{\circ} \mathrm{C}$ for $48 \mathrm{~h}$ and ground through a $1-\mathrm{mm}$ screen in a Wiley mill. Dried samples $(1 \mathrm{~g}$ ) of feed and feed refusals were ashed at $500{ }^{\circ} \mathrm{C}$ for $8 \mathrm{~h}$ and then $5 \mathrm{ml}$ of concentrated $\mathrm{HCl}(12 \mathrm{M})$ were added and heated to dissolve the ash completely. The mixture was filtered through P-free filter paper. Faecal samples $(1 \mathrm{~g})$ were dried at $105^{\circ} \mathrm{C}$ and ashed at $500{ }^{\circ} \mathrm{C}$ for $8 \mathrm{~h}$ and then $5 \mathrm{ml}$ of concentrated hydrochloric acid $(\mathrm{HCl} ; 12 \mathrm{M})$ were added for wet ashing digestion. The mixture was filtered through P-free filter paper. The urine samples were thawed, acidified $(12 \mathrm{M} \mathrm{HCL})$, dried at $55^{\circ} \mathrm{C}$ and ashed at $500{ }^{\circ} \mathrm{C}$. Then ashes were diluted $(3 \mathrm{M} \mathrm{HCl})$, filtered and volume made up to $10 \mathrm{ml}$. The blood samples were diluted in a solution of trichloroacetic acid (TCA, $100 \mathrm{~g}$ TCA/l distilled water), mixing $1 \mathrm{ml}$ with $9 \mathrm{ml} \mathrm{TCA}$ and then centrifuged at $1100 \times \mathbf{g}$ for $10 \mathrm{~min}$ at room temperature for plasma separation and protein precipitation. Samples of rumen fluid were diluted in a solution of TCA (100 g TCA/l distilled water) for protein precipitation $(0.5 \mathrm{ml}$ rumen fluid + $4.5 \mathrm{ml} \mathrm{TCA}$ ) and then centrifuged at $1800 \times \mathrm{g}$ for $10 \mathrm{~min}$ at room temperature. Samples of bone from each animal were cleaned and degreased with diethyl ether and thereafter acid-digested on a hot plate upon the addition of an aqueous solution of nitric acid $\left(500 \mathrm{ml} \mathrm{HNO}_{3} / \mathrm{l}\right)$. Then the samples were ashed in a muffle furnace at $550{ }^{\circ} \mathrm{C}$ and the residues were further digested using $10 \mathrm{ml}$ of an aqueous solution of $\mathrm{HCl}$ $(100 \mathrm{ml} \mathrm{HCl} / \mathrm{l})$ and filtered into a $25 \mathrm{ml}$ volumetric flask through P-free filter paper.

\section{Chemical analyses}

Feed samples were analysed for DM (method 934.01), ash (method 942.05), crude protein (method 984.13) and ADF (method 973.18) following recommendations of the Association of Official Analytical Chemists (AOAC 1995). Neutral detergent fibre (NDF) was analysed according to Mertens (2002), without using amylase or sodium sulphite.

Filtrates obtained after ashing and acid digestion of feed, orts, faeces, urine and bone samples, and supernatants obtained after centrifugation of plasma and rumen fluid samples were used for $\mathrm{P}$ and $\mathrm{Ca}$ analyses. Inorganic $\mathrm{P}$ was determined by colorimetry using vanadate molybdate reagent (Fiske \& Subbarow 1925; Sarruge \& Haag 1974). This colorimetric determination of $\mathrm{P}$ is an adaptation of method 965.17 of AOAC (1995). A vanadate solution was prepared by dissolving $2.5 \mathrm{~g}$ ammonium vanadate $\left(\mathrm{NH}_{4} \mathrm{VO}_{3}\right)$ in $500 \mathrm{ml}$ boiling water. After cooling, $350 \mathrm{ml}$ of concentrated nitric acid $\left(\mathrm{HNO}_{3}\right)$ were added and the solution was diluted to 1 litre with distilled water. For the molybdate aqueous solution, $50 \mathrm{~g}$ of ammonium molybdate $\left(\left(\mathrm{NH}_{4}\right)_{6} \mathrm{Mo}_{7} \mathrm{O}_{24}\right)$ were dissolved in hot distilled water. Cooled vanadate and molybdate solutions were combined $(1: 1, \mathrm{vol} / \mathrm{vol})$ to obtain the vanadate-molybdate reagent. Filtered ash solution or supernatants $(2 \mathrm{ml})$ were mixed thoroughly with $2 \mathrm{ml}$ of vanadate-molybdate reagent and $3 \mathrm{ml}$ of distilled water. The mixture was allowed to stand for $5 \mathrm{~min}$ and absorbance was read at $420 \mathrm{~nm}$ against a standard $\mathrm{P}$ curve (using solutions of potassium dihydrogen phosphate) to estimate the $\mathrm{P}$ concentration in samples. Calcium was determined by atomicabsorption spectrometry (Zagatto et al. 1979). 
Specific radioactivity $\left({ }^{45} \mathrm{Ca}\right.$ and $\left.{ }^{32} \mathrm{P}\right)$ was measured in faeces and plasma samples. In addition, ${ }^{32} \mathrm{P}$ was also measured in the rumen samples. These determinations were performed in a Beckman liquid scintillation spectrometer (model Is 5000 TA, Beckman-Coulter Inc., Fullerton, CA). Aliquots ( $1 \mathrm{ml})$ of centrifuged $(1100 \times \mathbf{g}$ for $10 \mathrm{~min})$ and filtered plasma and rumen fluid samples were directly dispensed into borosilicate vials with $10 \mathrm{ml}$ of a scintillation solution and placed in the spectrometer for counting. Faeces (1 g fresh matter) were ashed for inorganic $\mathrm{P}$ and $\mathrm{Ca}$ determination and ashes obtained were dissolved and digested in $10 \mathrm{ml}$ $18 \mathrm{~N} \mathrm{H}_{2} \mathrm{SO}_{4}$ for $1 \mathrm{~h}$ and then $1 \mathrm{ml}$ of this solution was transferred to counting vials and diluted with a scintillation solution $(1: 10$ or $1: 20(\mathrm{v} / \mathrm{v})$ depending on the expected radioactivity values) for radioactivity measurement. To improve the efficiency of radioactivity readings, an external standard calibration procedure of quench correction was used. Specific radioactivity (SA) in faeces, plasma or rumen fluid was expressed as $\mathrm{MBq}{ }^{45} \mathrm{Ca} / \mathrm{g}$ of $\mathrm{Ca}$ and $\mathrm{MBq}$ ${ }^{32} \mathrm{P} / \mathrm{g}$ of $\mathrm{P}$.

\section{Calculations}

Mineral intake (mg/kg BW/day) was calculated as:

Mineral intake $=\left(\mathrm{DMI} \times \mathrm{CaP}_{\text {feed }}\right) / \mathrm{BW}$

where DMI is the dry matter intake (kg DM/day), $\mathrm{CaP}_{\text {feed }}$ is the Ca or P content of the diet $(\mathrm{mg} / \mathrm{kg} \mathrm{DM})$ and BW is the body weight $(\mathrm{kg})$.

Endogenous faecal losses of $\mathrm{Ca}$ and $\mathrm{P}$ were calculated according to Lofgreen \& Kleiber (1953) as:

Endogenous faecal loss (mg/kg BW/day)

$$
\begin{aligned}
= & \left(\mathrm{SA}_{\text {faeces }} / \mathrm{SA}_{\text {plasma }}\right) \\
& \times \text { total faecal excretion }(\mathrm{mg} / \mathrm{kg} \mathrm{BW} / \text { day })
\end{aligned}
$$

where, $\mathrm{SA}_{\text {faeces }}$ and $\mathrm{SA}_{\text {plasma, }}$ are the $\mathrm{SA}$ in faeces and plasma, respectively. An average of SAs recorded on days 6 and 7 after injection of isotopes was used for the calculation, assuming isotopic conditions to approximate steady state after such time, once the difference between successive SA values (on days 6 and 7) was of little significance. Endogenous faecal loss of $\mathrm{Ca}$ and $\mathrm{P}$ was used to calculate the true absorption of $\mathrm{Ca}$ and $\mathrm{P}$ in the gastro-intestinal tract:

Mineral true absorption

$$
\begin{gathered}
=\text { Intake }-[\text { total faecal excretion } \\
- \text { endogenous faecal loss }]
\end{gathered}
$$

Mineral retention was calculated as:

Mineral retention $=$ Intake - total faecal excretion

$$
\text { - total urinary excretion }
$$

Phosphorus endogenous flow entering into the rumen $\left(S_{\mathrm{r}}\right)$ and $\mathrm{P}$ turnover time $(T)$ in the rumen were calculated according to Smith et al. (1955), from the total amount of $\mathrm{P}$ in the rumen ( $\mathrm{g}$ of $\mathrm{P}), \mathrm{P}$ intake (g/day) and SA of ${ }^{32} \mathrm{P}(\mathrm{MBq} / \mathrm{g} \mathrm{P})$ in the rumen fluid and in plasma as described in detail in Dias et al. (2009).

\section{Statistical analysis}

Experimental measurements of $\mathrm{Ca}$ and $\mathrm{P}$ were analysed as a completely random design using a general linear models procedure. The data were taken from 18 animals, six for each treatment (dicalcium phosphate ingestion). Means were compared using the Tukey test, declaring significant differences between means when $P<0 \cdot 05$. Polynomial orthogonal contrasts were performed using the GLM procedure (SAS 1999). Probability values for the linear response (orthogonal polynomial contrast) are reported. The correlations between the parameters expressed as Pearson product-moment correlation coefficients were determined using PROC CORR of SAS, whereas the linear regression equations between the two parameters were obtained using PROC REG.

\section{RESULTS}

DM intake was similar for both diets supplemented with dicalcium phosphate $(1.12$ and $1.13 \mathrm{~kg} /$ day for diets providing 12.5 and $25 \mathrm{~g}$ of dicalcium phosphate/day, respectively), whereas DM intake was reduced by $7 \%$ $(P<0 \cdot 05)$ with the unsupplemented diet $(1 \cdot 04 \mathrm{~kg} /$ day $)$.

\section{Calcium}

There were significant $(P<0 \cdot 05)$ differences among treatments in total and endogenous Ca excreted in faeces and Ca truly absorbed from the diet, whereas $\mathrm{Ca}$ excreted in urine was similar for all treatments $(P>0 \cdot 05)$ (Table 2). Endogenous faecal Ca was used to calculate true Ca availability coefficients, which were $0.54,0.41$ and 0.38 for $0,12.5$ and $25 \mathrm{~g}$ of dicalcium phosphate/day, respectively $(P<0 \cdot 05)$.

Calcium retention increased linearly with dicalcium phosphate intake $(P<0 \cdot 05)$, the greatest retention 
Table 2. Calcium intake ( $\mathrm{mg} / \mathrm{kg}$ BW/day), excretion ( $\mathrm{mg} / \mathrm{kg} B W /$ day), retention ( $\mathrm{mg} / \mathrm{kg} B W /$ day) and Ca in bone ( $\mathrm{mg} \mathrm{Ca/g}$ bone)

\begin{tabular}{|c|c|c|c|c|c|}
\hline & \multicolumn{3}{|c|}{ Dicalcium phosphate (g/day) } & \multirow[b]{2}{*}{ S.E.M. } & \multirow{2}{*}{$\begin{array}{l}P \text { value } \\
\text { Linear } \\
\text { response }\end{array}$} \\
\hline & 0 & $12 \cdot 5$ & 25 & & \\
\hline Ca intake & 108 & 207 & 309 & & \\
\hline Total Ca in faeces & 73 & 161 & 245 & $6 \cdot 2$ & $<0 \cdot 001$ \\
\hline Endogenous faecal Ca & 23 & 39 & 52 & $7 \cdot 5$ & $0 \cdot 014$ \\
\hline Ca in urine & $3 \cdot 2$ & $2 \cdot 9$ & $2 \cdot 9$ & $0 \cdot 63$ & $0 \cdot 796$ \\
\hline Dietary Ca truly absorbed & 57 & 84 & 117 & $7 \cdot 7$ & $<0.001$ \\
\hline Ca retention & 32 & 43 & 61 & $6 \cdot 1$ & $0 \cdot 004$ \\
\hline Ca in bone & 131 & 127 & 128 & $7 \cdot 5$ & $0 \cdot 846$ \\
\hline
\end{tabular}

Table 3. Phosphorus intake ( $\mathrm{mg} / \mathrm{kg} B W /$ day), excretion $(\mathrm{mg} / \mathrm{kg} B W /$ day), retention ( $\mathrm{mg} / \mathrm{kg} \mathrm{BW} /$ day) and $P$ in bone ( $m g$ P/g bone)

\begin{tabular}{|c|c|c|c|c|c|}
\hline & \multicolumn{3}{|c|}{ Dicalcium phosphate (g/day) } & \multirow[b]{2}{*}{ S.E.M. } & \multirow{2}{*}{$\begin{array}{l}P \text { value } \\
\text { Linear } \\
\text { response }\end{array}$} \\
\hline & 0 & $12 \cdot 5$ & 25 & & \\
\hline$P$ intake & 43 & 104 & 166 & & \\
\hline Total $P$ in faeces & 32 & 86 & 133 & $6 \cdot 0$ & $<0 \cdot 001$ \\
\hline Endogenous faecal P & 18 & 46 & 72 & $4 \cdot 5$ & $<0 \cdot 001$ \\
\hline$P$ in urine & 0.4 & $0 \cdot 3$ & $0 \cdot 8$ & $0 \cdot 18$ & 0.136 \\
\hline Dietary $\mathrm{P}$ truly absorbed & 29 & 64 & 105 & $2 \cdot 9$ & $<0.001$ \\
\hline$P$ retention & 11 & 18 & 33 & $4 \cdot 7$ & 0.004 \\
\hline $\mathrm{P}$ in bone & 54 & 54 & 53 & $2 \cdot 1$ & $0 \cdot 831$ \\
\hline
\end{tabular}

Table 4. Phosphorus concentration in rumen, endogenous $P$ flow to rumen and $P$ turnover time in the rumen

\begin{tabular}{|c|c|c|c|c|c|}
\hline & \multicolumn{3}{|c|}{ Dicalcium phosphate (g/day) } & \multirow[b]{2}{*}{ S.E.M. } & \multirow{2}{*}{$\begin{array}{l}P \text { value } \\
\text { Linear } \\
\text { response }\end{array}$} \\
\hline & 0 & $12 \cdot 5$ & 25 & & \\
\hline Phosphorus concentration in rumen ( $\mathrm{g} \mathrm{P} / \mathrm{l})$ & $0 \cdot 53$ & $0 \cdot 71$ & $0 \cdot 82$ & $0 \cdot 051$ & $0 \cdot 001$ \\
\hline Endogenous $\mathrm{P}$ flow to the rumen $(\mathrm{mg} / \mathrm{kg} \mathrm{BW} /$ day) & 15 & 27 & 42 & $3 \cdot 2$ & $<0.001$ \\
\hline $\mathrm{P}$ turnover time (days) & 1.5 & 0.9 & $0 \cdot 7$ & $0 \cdot 12$ & $<0 \cdot 001$ \\
\hline
\end{tabular}

corresponding to the highest intake of dicalcium phosphate. The concentration of $\mathrm{Ca}$ in bone was similar for all treatments $(P>0 \cdot 05)$.

\section{Phosphorus}

Daily ingestion of dicalcium phosphate had a significant $(P<0 \cdot 05)$ linear effect on total and endogenous $P$ excreted in faeces and $P$ truly absorbed from the diet, whereas urinary $\mathrm{P}$ was similar for all treatments $(P>0.05)$ (Table 3$)$. True $\mathrm{P}$ absorption coefficients were $0.66,0.62$ and 0.64 for the diets with $0,12.5$ and $25 \mathrm{~g}$ of dicalcium phosphate/day, respectively $(P>0 \cdot 05)$.

Retained $\mathrm{P}(\mathrm{mg} / \mathrm{kg}$ BW/day) was different among treatments $(P<0.05)$ (Table 3$)$ and increased linearly with dicalcium phosphate intake $(P<0 \cdot 05)$. However, the proportion of $\mathrm{P}$ retained related to $\mathrm{P}$ intake was not different among treatments: $0 \cdot 24,0 \cdot 17$ and $0 \cdot 20$ for 0 , 12.5 and $25 \mathrm{~g}$ of dicalcium phosphate/day $(P>0.05)$.

Phosphorus concentration in the rumen $(\mathrm{g} P / \mathrm{l})$ was lowest for the control and similar for the other 
treatments (Table 4). Calculated $\mathrm{P}$ flow into the rumen $\left(S_{\mathrm{r}}\right)$ increased linearly with ingested $\mathrm{P}$, whereas $\mathrm{P}$ turnover time $(T)$ decreased linearly with ingested $\mathrm{P}$ (Table 4).

Endogenous $\mathrm{P}$ excreted in faeces $(\mathrm{mg} / \mathrm{kg}$ BW/ day), was related to endogenous $P$ flow entering the rumen $\left(S_{\mathrm{r}}, \mathrm{mg} / \mathrm{kg} B W /\right.$ day $)$ as shown by the linear equation:

$S_{\mathrm{r}}=0.48$ (S.E. 0.069) $\times$ endogenous $\mathrm{P}$ in faeces

$$
+6.30 \text { (S.E. 3.53) }\left(n=18 ; R^{2}=0.75 ; P<0.001\right)
$$

Relationships between Ca and P

Endogenous $\mathrm{Ca}$ excreted in faeces was poorly related to endogenous $\mathrm{P}$ in faeces (both in $\mathrm{mg} / \mathrm{kg}$ BW/day):

Endogenous $\mathrm{P}$ in faeces $=0.60$ (S.E. 0.251 )

$$
\begin{aligned}
& \times \text { endogenous Ca in faeces } \\
& +22(\text { S.E. } 10 \cdot 8) \\
& \left(n=18 ; R^{2}=0 \cdot 26 ;\right. \\
& P=0.030)
\end{aligned}
$$

Dietary P truly absorbed ( $\mathrm{mg} / \mathrm{kg}$ BW/day) was related to Ca truly absorbed ( $\mathrm{mg} / \mathrm{kg} \mathrm{BW/day):}$

P truly absorbed $=0.85$ (S.E. 0.167)

$$
\begin{aligned}
& \times \text { Ca truly absorbed } \\
& -6.7(\text { S.E. } 15 \cdot 2) \\
& \left(n=18, R^{2}=0.62 ; P<0.001\right)
\end{aligned}
$$

However, when $\mathrm{Ca}$ and $\mathrm{P}$ true absorption were expressed as a proportion of the corresponding intakes, the relationship between the true absorption coefficients of both minerals was not significant:

$\mathrm{P}$ true absorption $=0.081$ (s.E. $0 \cdot 149)$

$$
\begin{aligned}
& \times \text { Ca true absorption } \\
& -0.603(\text { S.E. } 0.068) \\
& \left(n=18, R^{2}=0.018 ; P>0.05\right)
\end{aligned}
$$

Calcium to $P$ ratio was similar in bone $(P>0 \cdot 05): 2 \cdot 40$, 2.41 and 2.39 for diets providing $0,12.5$ and $25 \mathrm{~g}$ of dicalcium phosphate/day, respectively and both minerals were linearly correlated:

$$
\begin{aligned}
\mathrm{Ca}(\mathrm{mg} / \mathrm{g} \text { bone })= & 2 \cdot 0 \text { (S.E. } 0.49) \times \mathrm{P}(\mathrm{mg} / \mathrm{g} \text { bone }) \\
& -24 \text { (S.E. } 26 \cdot 40) \\
& \left(n=18 ; R^{2}=0.68 ; P<0.001\right) .
\end{aligned}
$$

\section{DISCUSSION}

Calcium and $\mathrm{P}$ were provided in the diet at levels considered deficient for the diet without dicalcium phosphate supplementation and above $\mathrm{Ca}$ and $\mathrm{P}$ requirements for 8-month-old sheep (late maturing) for diets supplemented with 12.5 and $25 \mathrm{~g}$ of dicalcium phosphate/day (as, according to NRC (2007), Ca and P requirements for these animals would be 130 and $98 \mathrm{mg} / \mathrm{kg}$ BW/day, respectively). Mineral shortage may explain the reduced feed intake in the unsupplemented group, as deficiency of P might result in appetite loss (NRC 2007).

\section{Calcium}

Dietary Ca was increased by supplementation with dicalcium phosphate. True absorption of $\mathrm{Ca}$ as a proportion of Ca intake was greatest for the control group, where dicalcium phosphate was not provided. Miller (1975) and Martz et al. (1999) also reported that true absorption of Ca decreased as dicalcium phosphate intake increased. Roque et al. (2007) reported a coefficient of 0.40 for true Ca absorption of dicalcium phosphate offered to sheep fed diets according to NRC (1985) recommendations for growing lambs. Their value is in close agreement with that observed in the current study for the group receiving either $12.5 \mathrm{~g}$ of dicalcium phosphate/day, which provided the same amount of $\mathrm{Ca}$ as in Roque et al. (2007) or $25 \mathrm{~g}$ of dicalcium phosphate/day, which provided a higher amount of dietary Ca. However, this value $(0 \cdot 40)$ is well below the value of $\mathrm{Ca}$ absorption of 0.68 suggested by NRC (2007) for growing lambs. According to Chrisp et al. (1989a), the maximum or 'potential' availability should be assessed in animals in which intake is lower than the requirement, which would explain the highest $\mathrm{Ca}$ availability in the unsupplemented diet.

Young et al. (1966) did not observe a correlation between endogenous faecal $\mathrm{Ca}$ and absorption of Ca. However, in their study Ca intake did not affect endogenous Ca excretion in faeces, as observed in the present study (Table 2). Braithwaite (1982) reported a significant linear relationship between endogenous faecal loss of $\mathrm{Ca}$ and feed intake, whereas endogenous Ca excretion was unaltered by Ca intake. Conversely, Chrisp et al. (1989b) showed a positive relationship between $\mathrm{Ca}$ intake and endogenous faecal $\mathrm{Ca}$ in growing and lactating sheep. Chrisp et al. (1989b) concluded that simple relationships between endogenous Ca excretion and either feed or Ca intake 
do not account for the complexity of the processes occurring in the gut. Therefore, along with a greater loss of endogenous $\mathrm{Ca}$ associated with increased feed intake, there is a variable faecal endogenous loss of $\mathrm{Ca}$, which is dependent on the net $\mathrm{Ca}$ requirement in relation to $\mathrm{Ca}$ intake or the amount of $\mathrm{Ca}$ available for absorption in the alimentary tract (Chrisp et al. 1989b). According to those authors, when the demand for $\mathrm{Ca}$ is high and the pool of absorbable $\mathrm{Ca}$ is small, a greater proportion of endogenous Ca secreted is re-absorbed resulting in lower excretion of endogenous $\mathrm{Ca}$ in faeces. This assumption offers a reasonable explanation for the lowest endogenous faecal Ca excretion in the unsupplemented control group. Likewise, Martz et al. (1999) observed low endogenous faecal excretion of Ca in ruminants fed small amounts of feed with low intakes of Ca. Endogenous faecal Ca values for the supplemented lambs were within the range (35-50 mg/kg BW/day) found by Chrisp et al. (1989b) for young sheep fed 1.5-2 times the estimated maintenance energy requirement.

Concentration of $\mathrm{Ca}$ in bone was not affected by increasing intakes of dicalcium phosphate. The short experimental period could explain the lack of response regarding $\mathrm{Ca}$ concentration in bone with increasing ingestion of $\mathrm{Ca}$ and there are studies showing that $\mathrm{Ca}$ ingestion may not affect the concentration of $\mathrm{Ca}$ in bone. Braithwaite \& Riazuddin (1971) observed no changes in the rapidly and slowly exchangeable bone Ca pool in young and mature sheep fed variable amounts of Ca, while Belonje \& van den Berg (1983) observed no significant change in bone Ca concentration related to $\mathrm{Ca}$ intake in sheep fed different amounts of $\mathrm{Ca}$ and $\mathrm{P}$ for 98 days. In the current study, other bone measurements such as bone ash and bone DM content were not significantly different among treatments (data not shown).

\section{Phosphorus}

Dicalcium phosphate is a common dietary $\mathrm{P}$ supplement used in animal diets. Lofgreen (1960) reported $0 \cdot 50$ as the true availability of this source of dietary $\mathrm{P}$, noticeably lower than the average values observed in the present study, which ranged from 0.62 to 0.66 . The different true $\mathrm{P}$ absorption coefficients are probably related to the category of animal used for study, as growing animals are able to absorb nutrients more efficiently than mature animals (Braithwaite \& Riazuddin 1971). In a meta-analysis study, Bravo et al. (2003) found true P absorption coefficients of $0 \cdot 60$ and 0.70 for diets containing large amounts of hay and silage, respectively. The database used included results from studies in sheep, cattle and goats in different physiological and productive states (growing, lactating, gestating, etc.), and with diets covering a wide range of $\mathrm{P}$ contents (from $2 \cdot 0$ to $6.4 \mathrm{~g}$ of $\mathrm{P} / \mathrm{kg} \mathrm{DM}$ ). According to Bravo et al. (2003), the efficiency of $\mathrm{P}$ absorption decreases when concentration of $\mathrm{P}$ in the digestive tract is high, due to the combination of saturated active absorption and passive diffusion. It seems that in the current study the difference between $P$ intakes was not enough to affect true $\mathrm{P}$ absorption $(P>0 \cdot 05)$.

Endogenous $\mathrm{P}$ loss in the control diet (unsupplemented) was close to value of $20 \mathrm{mg} / \mathrm{kg}$ BW/day used by NRC (1985) as the total endogenous losses for growing sheep. Loss of metabolic $\mathrm{P}$ is expected even in animals fed an inadequate $P$ diet (Vitti et al. 2000). Endogenous $\mathrm{P}$ loss in all treatments represented approximately 0.55 of total faecal $\mathrm{P}$, which is noticeably lower than the 0.85 value suggested by NRC (2007) as the proportion of endogenous faecal P present in total $\mathrm{P}$ excreted in faeces. However, the values found in the present paper are in line with the values reported by Lofgreen (1960) who reported that endogenous faecal $\mathrm{P}$ accounted for 0.56 of total $\mathrm{P}$ excreted in faeces of mature wethers. As a result of the significant contribution of endogenous $P$ to total faecal excretion, true $P$ availability was $0.66,0.62$ and $0 \cdot 64$, whereas apparent availability was $0 \cdot 25,0 \cdot 18$ and $0 \cdot 21$ for dicalcium phosphate intakes of $0,12 \cdot 5$ and $25 \mathrm{~g}$ /day.

Endogenous $\mathrm{P}$ excreted in faeces was related to endogenous $\mathrm{P}$ flow entering the rumen $\left(S_{\mathrm{r}}\right)(r=0 \cdot 86)$ and both increased linearly with increasing dicalcium phosphate intake. In agreement, Dias et al. (2009) found that $\mathrm{P}$ intake in sheep supplemented with monoammonium phosphate affected positively endogenous $\mathrm{P}$ flow to the rumen and inversely $\mathrm{P}$ turnover, as observed in the current study (Table 4). The flows of endogenous $\mathrm{P}$ entering the rumen were smaller than those for endogenous $P$ excreted in faeces, indicating a contribution of endogenous $P$ from the lower gastrointestinal tract.

Endogenous $\mathrm{P}$ in faeces and $\mathrm{P}$ intake were inversely related to $\mathrm{P}$ turnover $(r=-0.68$ and $r=-0.78$, respectively). According to Young et al. (1966), a greater metabolic faecal $\mathrm{P}$ excretion associated with increased $\mathrm{P}$ intake suggests an accelerated rate of $\mathrm{P}$ secretion to the gastrointestinal tract and thus a shorter turnover time of $\mathrm{P}$ in the digestive compartments. 
Phosphorus intake affected linearly $\mathrm{P}$ concentration in the rumen (Table 4). Secretion of $P$ through saliva also contributes to $\mathrm{P}$ in the rumen (Bannink et al. 2010), as shown earlier by the flow of endogenous $P$ entering the rumen. Salivary $P$ is important not only as a buffer against volatile fatty acids but also as a means to control the amount of $\mathrm{P}$ secreted into the gut (Tomas $1974 a, b)$. In contrast, very small amounts of Ca are returned to the rumen via saliva secretion (Grace et al. 1985), explaining why for Ca the endogenous loss accounts for a smaller proportion of total faecal excretion than for $\mathrm{P}$.

Concentration of $\mathrm{P}$ in bone was not affected by dicalcium phosphate intake (Table 3). Accordingly, Wan Zahari et al. (1990) did not observe differences in $\mathrm{P}$ concentration in the bone of sheep fed different amounts of this mineral. Conversely, other studies showed a correlation between $\mathrm{P}$ intake and $\mathrm{P}$ content in bone (Williams et al. 1991; Esser et al. 2009). The lack of effect of dietary P on P content in bone could be related to the short timeframe of the experiment.

\section{Calcium and phosphorus interactions}

Calcium retention was weakly related to $\mathrm{P}$ retention $(r=0 \cdot 30)$. Conversely, Braithwaite (1984) found a strong correlation between the retention of these minerals using data from several studies with sheep. However, Ca truly absorbed from the diet was related to dietary $\mathrm{P}$ truly absorbed $(r=0 \cdot 81)$. This relationship can be explained by the fact that as the intake of both minerals is increased, the amount of each mineral truly absorbed is also increased. Indeed, when true absorption coefficients (g truly absorbed/g ingested) were correlated, the relationship was not significant $(r=0 \cdot 14, P=0 \cdot 593)$. The absorption of these minerals is uncoupled to allow the absorption of each element to be adjusted to differences in physiological demand (Pfeffer et al. 2005). The metabolism of $\mathrm{Ca}$ and $\mathrm{P}$ are closely related and the excess or deficit of one mineral may affect the utilization of the other (Veum 2010). However, in ruminants the Ca to $P$ ratio only affects the absorption of these minerals if the diet is inadequate in Ca and P (Veum 2010) and optimal performance in ruminants can be attained with dietary $\mathrm{Ca}$ to $\mathrm{P}$ ratios ranging from $1 \cdot 5: 1$ to $2 \cdot 5: 1$ (NRC 2007). The Ca : P ratios of the three diets used in the current experiment fell within this range and thus it can be expected that the $\mathrm{Ca}: \mathrm{P}$ ratio did not affect the absorption of either mineral. Chapuis-Lardy et al. (2004) suggested that $\mathrm{P}$ supplementation by adding monocalcium or dicalcium phosphate to ruminant diets increased faecal excretion of P and Ca. Roque et al. (2007), assessing the availability of different sources of Ca to growing sheep, found that $\mathrm{Ca}$ from dicalcium phosphate was less available than Ca from limestone, probably due to the link between $\mathrm{Ca}$ and $\mathrm{P}$ in the former source. The lack of mineral supplementation in the control treatment associated with slightly greater $\mathrm{Ca}$ and $\mathrm{P}$ availability for this treatment suggests that the $\mathrm{Ca}$ and $\mathrm{P}$ present in an organic form together with the low level of $\mathrm{Ca}$ and $\mathrm{P}$ in this diet may have favoured utilization of these minerals. Rumen microbes and their enzymes are able to digest organic forms of these minerals leading to their efficient absorption from the gastrointestinal tract (Bravo et al. 2003; Kincaid \& Rodehutscord 2005; Bannink et al. 2010).

Endogenous $\mathrm{Ca}$ in faeces was poorly correlated with endogenous P excreted in faeces $(r=0 \cdot 48)$. This weak relationship would be a result of the different roles of endogenous $\mathrm{Ca}$ and endogenous $\mathrm{P}$ in the metabolism of these elements.

The Ca : $\mathrm{P}$ ratio in bone was similar for all treatments with a mean value of $2 \cdot 4$. This ratio is greater than the stoichiometric value of hydroxyapatite $(2 \cdot 16)$, which is the main mineral form in which $\mathrm{Ca}$ and $\mathrm{P}$ are accreted in bone. This difference suggests that sheep were mineralizing the bone matrix with $\mathrm{Ca}$ present in carbonate form. Taylor et al. (2009) observed a dietary $\mathrm{Ca}$ effect on bone Ca but not on bone $\mathrm{P}$ and suggested that bone was mineralized with Ca in carbonate form.

Although supplementation with dicalcium phosphate is recommended under some circumstances, especially for diets deficient in $\mathrm{Ca}$ and $\mathrm{P}$, this nutritional strategy needs to be implemented with caution in order to avoid increased feeding costs and unnecessary waste of these minerals, which would consequently cause a potential environmental problem.

Funding was provided, in part, by the Canada Research Chairs and NSERC Discovery programs. JF and SL gratefully acknowledge receipt of collaborative grant no. SAB2010-0151 from the Spanish 'Ministerio de Educación' under the programme 'Programa Nacional de Movilidad de Recursos Humanos del Plan Nacional de I-D +i 2008-2011-subprograma EXTESP-EDU' to undertake this work.

\section{REFERENCES}

Ammerman, C.B., Forbes, R.M., Garrigus, U.S., Newmann, A. L., Norton, H. W. \& Hatfield, E. E. (1957). 
Ruminant utilization of inorganic phosphates. Journal of Animal Science 16, 796-810.

Arrington, L. R., Outler, J. C., Ammerman, C. B. \& Davis, G. K. (1963). Absorption, retention and tissue deposition of labeled inorganic phosphate by cattle. Journal of Animal Science 22, 940-942.

Association of Official Analytical Chemists (AOAC) (1995). Official Methods of Analysis of AOAC, 16th edn. Arlington, VA, USA: Association of Official Analytical Chemists International.

BANNINK, A., Š EBEK, L. \& DiJKSTRA, J. (2010). Efficiency of phosphorus and calcium utilization in dairy cattle and implications for the environment. In Phosphorus and Calcium Utilization and Requirements in Farm Animals (Eds D. M.S.S. Vitti \& E. Kebreab), pp. 151-172. Wallingford, UK: CAB International.

Belonje, P. C. \& Van Den Berg, A. (1983). Failure of bone phosphorus levels to indicate dietary intake of phosphorus by sheep. Onderstepoort Journal of Veterinary Research 50, 1-2.

Braithwaite, G. D. (1982). Endogenous faecal loss of calcium by ruminants. Journal of Agricultural Science, Cambridge 99, 355-358.

BraithWAite, G. D. (1984). Some observations on phosphorus homeostasis and requirement of sheep. Journal of Agricultural Science, Cambridge 102, 295-306.

Braithwaite, G. D. \& Riazuddin, S. (1971). The effect of age and level of dietary calcium intake on calcium metabolism in sheep. British Journal of Nutrition 26, 215-225.

Bravo, D., Sauvant, D., Bogaert, C. \& Meschy, F. (2003). II. Quantitative aspects of phosphorus absorption in ruminants. Reproduction Nutrition Development 43, 271-284.

Chapuis-Lardy, L., Fiorini, J., Toth, J. \& Dou, Z. (2004). Phosphorus concentration and solubility in dairy feces: variability and affecting factors. Journal of Dairy Science 87, 4334-4341.

Chrisp, J.S., Sykes, A.R. \& Grace, N.D. (1989a). Kinetic aspects of calcium metabolism in lactating sheep offered herbages with different $\mathrm{Ca}$ concentrations and the effect of protein supplementation. British Journal of Nutrition 61, 45-58.

ChrisP, J.S. \& Sykes, A. R. \& Grace, N.D. (1989b). Faecal endogenous loss of calcium in young sheep. British Journal of Nutrition 61, 59-65.

Dias, R. S., Lopez, S., Silva, T., Pardo, R. M.P., Silva Filho, J. C., Vitti, D.M.S.S., Kebreb, E. \& France, J. (2009). Rumen phosphorus metabolism in sheep. Journal of Agricultural Science, Cambridge 147, 391-398.

Esser, N. M., Hoffman, P. C., Coblentz, W. K., Orth, M. W. \& WeIGEL, K. A. (2009). The effect of dietary phosphorus on bone development in dairy heifers. Journal of Dairy Science 92, 1741-1749.

Fiske, C. H. \& Subbarow, Y. (1925). The colorimetric determination of phosphorus. Journal of Biological Chemistry 66, 375-400.

France, J., Dias, R.S., Kebreab, E., Vitti, D.M.S.S., Crompton, L. A. \& LóPEZ, S. (2010). Kinetic models for the study of phosphorus metabolism in ruminants and monogastrics. In Phosphorus and Calcium Utilization and Requirements in Farm Animals (Eds D. M. S. S. Vitti
\& E. Kebreab), pp. 18-44. Wallingford, Oxon, UK: CAB International.

Grace, N. D., Carr, D. H. \& Reid, C. S. W. (1985). Secretion of sodium, potassium, phosphorus, calcium, and magnesium via the parotid and mandibular saliva in sheep-offered chaffed lucerne hay or fresh 'Grasslands Ruanui' perennial ryegrass. New Zealand Journal of Agricultural Research 28, 449-455.

Johnson, R. R. \& McClure, K.E. (1967). Sequestering phosphatic solution as a phosphorus source for ruminants. Journal of Dairy Science 50, 1502-1504.

KinCaID, R. L. \& Rodehutscord, M. (2005). Phosphorus metabolism in the rumen. In Nitrogen and Phosphorus Nutrition of Cattle and the Environment (Eds E. Pfeffer \& A. Hristov), pp. 187-193. Wallingford, Oxon, UK: CAB International.

LOFGREEN, G. P. (1960). The availability of the phosphorus in dicalcium phosphate, bonemeal, soft phosphate and calcium phytate for mature weathers. Journal of Nutrition 70, 58-62.

Lofgreen, G. P. \& Kleiber, M. (1953). The availability of the phosphorus in alfalfa hay. Journal of Animal Science 12, 366-371.

Long, T. A., Tillman, A. D., Nelson, A. B., Gallup, W. D. \& DAvIS, B. (1957). Availability of phosphorus in mineral supplements for beef cattle. Journal of Animal Science 16, 444-450.

Martz, F. A., Belo, A. T., Weiss, M. F. \& Belyea, R. L. (1999). True absorption of calcium and phosphorus from corn silage fed to nonlactating, pregnant dairy cows. Journal of Dairy Science 82, 618-622.

Mertens, D. R. (2002). Gravimetric determination of amylase-treated neutral detergent fiber in feeds using refluxing in beakers or crucibles: collaborative study. Journal of AOAC International 82, 1217-1240.

Miller, W. J. (1975). New concepts and developments in metabolism and homeostasis of inorganic elements in dairy cattle: a review. Journal of Dairy Science 58, 1549-1560.

National Research Council (NRC) (1985). Nutrient Requirements of Sheep, 6th Revised edn. Washington, DC: National Academy Press.

National Research Council (NRC) (2007). Nutrient Requirements of Small Ruminants. Washington, DC: National Academy Press.

O’Donovan, J.P., Plumlee, M.P., Smith, W. H. \& BEESON, W.M. (1965). Availability of phosphorus in dicalcium phosphates and defluorinated phosphate for steers. Journal Animal Science 24, 981-985.

Pfeffer, E., Beede, D. K. \& Valk, H. (2005). Phosphorus metablolism in ruminants and requirements of cattle. In Nitrogen and Phosphorus Nutrition of Cattle and the Environment (Eds E. Pfeffer \& A. Hristov), pp. 195-231. Wallingford, Oxon, UK: CAB International.

Roque, A. P., Dias, R. S., Vitti, D. M. S. S., da Silva Bueno, I. C., da Cunha, E. A., dos Santos, L. E. \& Bueno, M. S. (2007). True digestibility of calcium from source used in finishing lambs diets. Small Ruminant Research 71, 243-249.

SAS Institute Inc. (1999). SAS/STAT User's Guide Version 8. Cary, NC: SAS Institute Inc. 
Sarruge, J. R. \& HaAG, H.P. (1974). Chemical Analysis of Plants. Piracicaba, Brazil: Departamento de Química, Escola Superior de Agricultura 'Luiz de Queiroz'.

Smith, A. H., Kleiber, M., Black, A. L. \& Baxter, C. F. (1955). Transfer of phosphate in the digestive tract. II. Sheep. Journal of Nutrition 57, 507-527.

Taylor, M. S., KnOWlton, K. F., McGilliard, M. L., SweCker W. S., Ferguson, J. D., Wu, Z. \& Hanigan, M. D. (2009). Dietary calcium has little effect on mineral balance and bone mineral metabolism through twenty weeks of lactation in Holstein cows. Journal of Dairy Science 92, 223-237.

Tillman, A. D. \& Brethour, J. R. (1958). Dicalcium phosphate and phosphoric acid as phosphorus sources for beef cattle. Journal of Animal Science 17, 100-103.

TOMAs, F. M. (1974a). Phosphorus homeostasis in sheep. II. Influence of diet on the pathway of excretion of phosphorus. Australian Journal of Agricultural Research 25, 485-493.

TOMAs, F. M. (1974b). Phosphorus homeostasis in sheep. III. Relationship between the amount of salivary phosphorus secreted and the quantities of phosphorus excreted via the urine and faeces. Australian Journal of Agricultural Research 25, 495-507.

VeUm, T. L. (2010). Phosphorus and calcium nutrition and metabolism. In Phosphorus and Calcium Utilization and Requirements in Farm Animals (Eds. E. Kebreab \& D.M.S.S. Vitti), pp. 94-111. Wallingford, UK: CAB International.

Vitti, D. M. S. S., Kebreab, E., Lopes, J. B., Abdalla, A. L., de Carvalhos, F.F. R., de Resende, K.T., Crompton, L. A. \&
FrancE, J. (2000). A kinetic model of phosphorus metabolism in growing goats. Journal of Animal Science 78, 2706-2712.

Vitti, D. M. S. S., Silva-Filho, J. C., Louvandini, H., Dias, R. S., Bueno, I. C.S. \& Kebreab, E. (2010). Phosphorus and calcium utilization in ruminants using isotope dilution techniques. In Phosphorus and Calcium Utilization and Requirements in Farm Animals (Eds D. M. S. S. Vitti \& E. Kebreab), pp. 45-67. Wallingford, UK: CAB International.

Wan Zahari, M., Thompson, J. K., SCOtT, D. \& Buchan, W. (1990). The dietary requirements of calcium and phosphorus for growing lambs. Animal Production 50, 301-307.

Williams, S. N., Lawrence, L. A., McDowell, L. R., Wilkinson, N.S., Ferguson, P.W. \& Warnick, A.C. (1991). Criteria to evaluate bone mineralization in cattle: effects of dietary phosphorus on chemical, physical and mechanical properties. Journal of Animal Science 69, 1232-1242.

YounG, V.R., LOFGreEn, G.P. \& LUICK, J.R. (1966). The effects of phosphorus depletion, and of calcium and phosphorus intake, on the endogenous excretion of these elements by sheep. British Journal of Nutrition 20, 795-805.

Zagatto, E. A. G., Krug, F. J., Bergamim Filho, H., Jorgensen, S. S. \& Reis, B. F. (1979). Margin zones in flow injection analysis. Part 2. Determination of calcium, magnesium and potassium in plant material by flow injection atomic and flame emission spectrometry. Analytica Chimica Acta 104, 279-284. 